\title{
Thermal conductivity and thermal diffusivity of cores from a 26 meter deep borehole drilled in Livingston Island, Maritime Antarctic
}

\author{
A. Correia ${ }^{\mathrm{a}, *}, \mathrm{G}$. Vieira ${ }^{\text {b }}$, M. Ramos ${ }^{\mathrm{c}}$ \\ a Centro de Geofisica de Évora, Universidade de Évora, Évora, Portugal \\ b Centro de Estudos Geográficos, Universidade de Lisboa, Lisboa, Portugal \\ c Universidad de Alcalá, 28871 Madrid, Spain
}

\section{A R T I C L E I N F O}

\section{Article history:}

Received 10 February 2011

Accepted 7 December 2011

Available online 14 December 2011

\section{Keywords:}

Thermal conductivity

Thermal diffusivity

Livingston Island

Antarctic Peninsula

\begin{abstract}
A B S T R A C T
During the month of January of 2008 a borehole (Permamodel-Gulbenkian 1 - PG1) 26 m deep was drilled on the top of Mount Reina Sofia (275 m a.s.l.) near the Spanish Antarctic Station of Livingston Island, South Shetland Islands. Cores from $1.5 \mathrm{~m}$ to about $26 \mathrm{~m}$ deep were collected for measuring several physical properties. The objective of the present work is to report the values of the thermal conductivity and the thermal diffusivity that were measured in the cores from the borehole and the heat production that was estimated for the geological formations intercepted by it. Seven cores were selected to measure the thermal conductivity and the thermal diffusivity. The measured values for the thermal conductivity vary from $2.6 \mathrm{~W} / \mathrm{mK}$ to $3.3 \mathrm{~W} / \mathrm{mK}$ while the measured values for the thermal diffusivity vary from $1.1 \times 10^{-6} \mathrm{~m}^{2} / \mathrm{s}$ to $1.6 \times 10^{-6} \mathrm{~m}^{2} / \mathrm{s}$. Both thermal conductivity and thermal diffusivity, on average, show a slight increase with depth. Average heat production was also estimated for two portions of the borehole: one from 2 to $12 \mathrm{~m}$ and the other from 12 to $25 \mathrm{~m}$. A gamma-ray spectrometer was used to estimate the concentrations of uranium, thorium, and potassium of the cores, from which the heat production per unit volume was calculated. The estimated heat production for the first half of the borehole is $2.218 \mu \mathrm{W} / \mathrm{m}^{3}$ while for the second half it is $2.173 \mu \mathrm{W} / \mathrm{m}^{3}$; these heat production values are compatible with acidic rock types. Porosity and density were also estimated for the same cores.
\end{abstract}

(c) 2012 Elsevier B.V. All rights reserved.

\section{Introduction}

Thermal conductivity is one of the major factors that affect the temperature distribution in the ground. As a result of different thermal conductivities in the ground its thermal structure may change laterally as well as vertically. On the other hand, thermal diffusivity, which controls the rate at which heat dissipates through a material, is also important in processes where temperature changes with time. Even though there is agreement about the importance of those two physical properties of rocks in the study of the thermal regime of the ground, not many measurements have been performed on rocks of permafrost areas. In contrast with the thermal conductivity and the thermal diffusivity, the heat generated by radioactive decay in rocks has an effect of about 20 to $50 \%$ in the temperature distribution in the ground (Blackwell and Steele, 1989); however, the importance of the heat production in rocks in heat flow studies and modeling the thermal regime of the ground cannot be denied. The work reported in this paper is an attempt to fill the gap in knowledge concerning the actual measurements of physical properties of rocks in permafrost areas and attempts to start a systematic measurement of those physical properties

\footnotetext{
* Corresponding author.

E-mail address: correia@uevora.pt (A. Correia).
}

to better understand the thermal regime in permafrost areas and model their thermal regime.

Antarctic permafrost conditions are relatively poorly known (Bockheim, 1995). By the end of 2010 nine shallow (active layer) boreholes in the Antarctic Peninsula region are being used to monitor temperature (Bockheim and Hall, 2004; Guglielmin, 2006; Amaral et al., 2010; Ramos et al., 2010). The same has been done for several boreholes in continental Antarctica (Guglielmin and Cannone, 2011; Guglielmin et al., 2011).

The Antarctic Peninsula has a mild and humid climate (King and Turner, 1997; Van de Berg et al., 2008) and has experienced a rapid mean annual air temperature (MAAT) increase of about $2.58{ }^{\circ} \mathrm{C}$ over the last 50 years (King, 1994; Turner et al., 2005). It is the only land mass in its latitudinal range and so the knowledge of the atmospheric conditions and related phenomena in the Antarctic Peninsula are important to study changes in the Antarctic climate and atmospheric circulation.

Permafrost evolution and spatial distribution are good indicators of climate change; in the northern part of the Antarctic Peninsula permafrost is often discontinuous. Permafrost areas are also very sensitive to changes in temperature and precipitation and so affects geomorphic processes (Ramos and Vieira, 2003; Ramos et al., 2008a,b).

This short paper presents the results of a study performed on cores obtained in a borehole $26 \mathrm{~m}$ deep (Permamodel-Gulbenkian 1 - PG1) that was drilled and instrumented in 2008 on the top of Mount Reina 
Sofia (275 m a.s.l.) near the Spanish Antarctic Station in Livingston Island, South Shetland Islands (Fig. 1). Since this borehole is intended for long-term permafrost monitoring, this paper describes the physical properties measured in the cores collected from it so that estimates of the past climate evolution can be made and energy processes at permafrost and active layer levels can be studied. Thermal conductivity, thermal diffusivity, heat production, density, and porosity were measured in the cores of PG1 borehole. These data are of particular interest and importance in the case of the Antarctic Peninsula and high latitudes, in general, because the climate change that is occurring will change the surface heat balance as well as the soil temperature and hence the distribution and evolution of permafrost. Furthermore, those properties affect the thermal regime of the permafrost areas and the active layer and so are important to interpret past and present soil temperature.

\section{Study site and borehole location}

Livingston Island is located at $62^{\circ} 39^{\prime} \mathrm{S}, 60^{\circ} 21^{\prime} \mathrm{W}$ in the South Shetland Islands. The climate at sea level is cold maritime, with frequent summer rainfall and a moderate annual temperature range. The climate reflects the strong influence of the circum-Antarctic low-pressure system and meteorological conditions in summer are dominated by the continuous influence of polar frontal systems (Styszynska, 2004). Relative humidity is usually high, with average values of $80-90 \%$. King George Island of the South Shetlands Islands shows a MAAT of $-1.6^{\circ} \mathrm{C}$ at sea level and an annual precipitation of about $500 \mathrm{~mm}$ (Ramos et al., 2009). Permafrost in the South Shetland Islands is widespread above the Holocene raised beaches about 30 m a.s.l. (Serrano and Lopez-Martinez, 2000; Hauck et al., 2007). Air temperatures measured in the Spanish Antarctic Station in Livingston Island, at $15 \mathrm{~m}$ a.s.l., show MAATs from year 2000 to year 2006 that range from $-3.2{ }^{\circ} \mathrm{C}$ to $-1.5^{\circ} \mathrm{C}$. From April to November, the average daily temperatures at sea level are generally below $0{ }^{\circ} \mathrm{C}$ and from December to March they are generally positive.

In the year 2008 a $26 \mathrm{~m}$ deep borehole (PG1 borehole) was drilled in Mount Reina Sofia (Fig. 1). Near the site of the borehole the MAAT
(2003-2006) was $-4.2^{\circ} \mathrm{C}$ (Ramos et al., 2008b) and mean annual ground temperatures measured since 2000 (at depths of 15, 25, 40, and $90 \mathrm{~cm}$ in a $1.1 \mathrm{~m}$ borehole) vary between $-2.6{ }^{\circ} \mathrm{C}$ and $-2.1{ }^{\circ} \mathrm{C}$. The measured active layer thickness, based on direct observations in pits and temperature data, was approximately $70 \mathrm{~cm}$ (Ramos et al., 2008a); however, since 2003, the thickness has increased to $90 \mathrm{~cm}$.

Geoelectrical and seismic surveys performed in the area of the PG1 borehole indicate a $0.5-1 \mathrm{~m}$ thick unfrozen layer with relatively low electrical resistivities (1000-2000 $\Omega-\mathrm{m}$ ) and low P-wave velocities (500-1000 m/s) above a 3-4 m thick layer with high electrical resistivities (7000-10,000 $\Omega-\mathrm{m})$ and medium to high P-wave velocities (2500-5500 m/s) representing weathered shales. Below that layer, electrical resistivities decrease to values of 1500-2000 $\Omega$-m indicating low ice contents in a fairly competent bedrock (Hauck et al., 2007). The $26 \mathrm{~m}$ borehole, called Permamodel-Gulbenkian 1 (PG1) is within the CALM (Circumpolar Active Layer Monitoring) site of the Mount Reina Sofia. The above mentioned $1.1 \mathrm{~m}$ borehole was drilled in 2000 is about $40 \mathrm{~m}$ south of PG1. The coordinates of the PG1 borehole are: $\mathrm{N}$ $3048545.4 \mathrm{~m}$, E $634145.1 \mathrm{~m}$, and $272 \mathrm{~m}$ a.s.l. in the Universal Transverse Mercantor Coordinate system (UTM) zone 20 south. Fig. 2 is a picture of the site where the borehole was drilled and shows a phase of the drilling process.

\section{Methods}

The thermal conductivities and the thermal diffusivities of the cores from PG1 borehole were measured in a TCS Lippmann \& Rauen Gbr equipment. This equipment allows measuring thermal conductivity and thermal diffusivity of samples or cores as small as $40 \times 40 \times 40 \mathrm{~mm}^{3}$ simultaneously; thermal conductivity accuracy is $3 \%$ with a measurement range of 0.2 to $25.0 \mathrm{~W} / \mathrm{mK}$, while thermal diffusivity accuracy is $5 \%$ with a measurement range of 0.6 to $3.0 \times 10^{-6} \mathrm{~m}^{2} / \mathrm{s}$. The measurements were performed on dry cores at room temperature. The measuring device consists of a point like heat source that is moved along the core to be measured. The temperatures before and after heating are measured and used to calculate the thermal conductivity; both

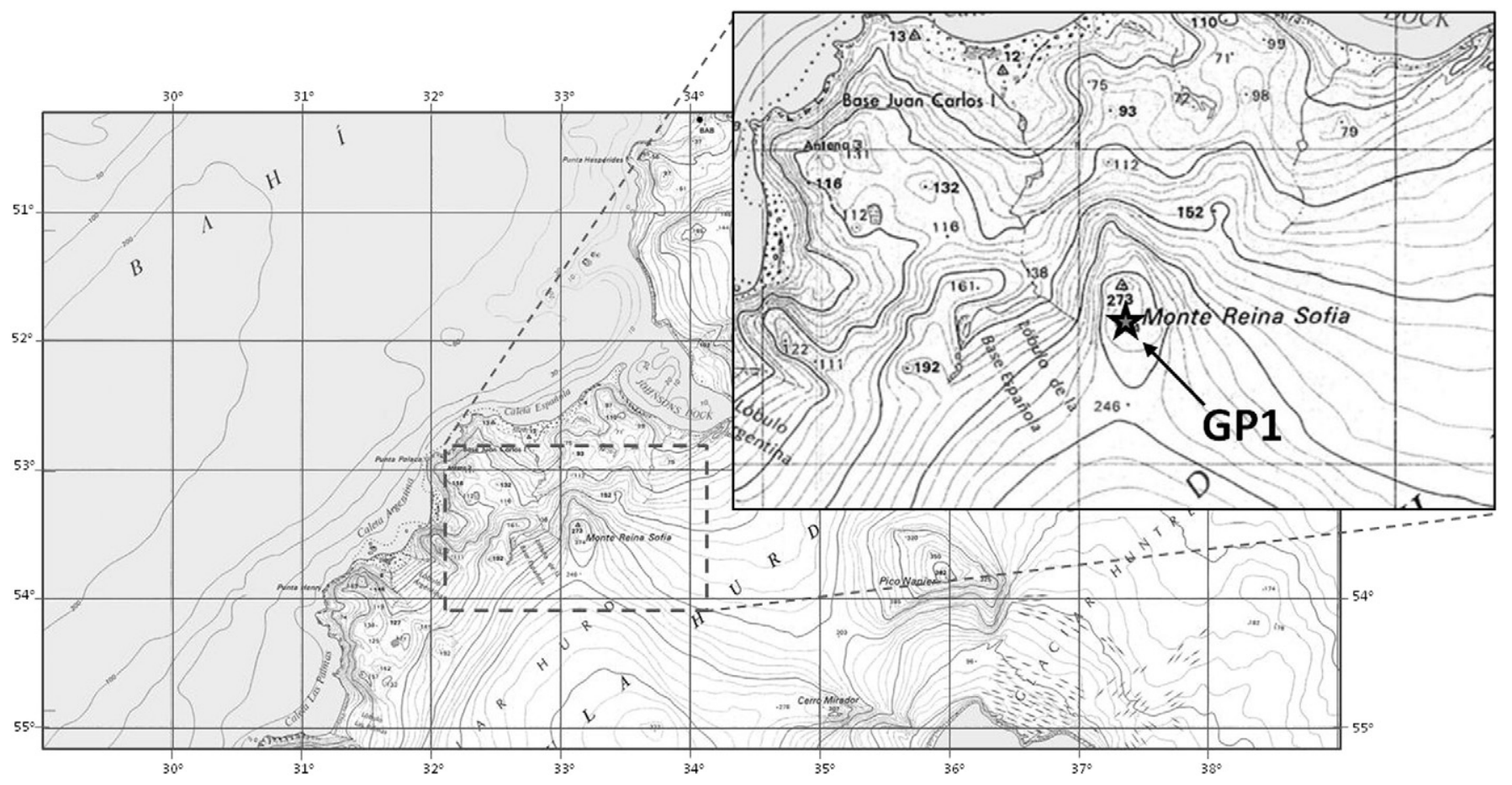

Fig. 1. Location of the PG1 borehole (star) in the Reina Sofia Mountain near the Spanish Antarctic Station (Station Juan Carlos I) in Livingston Island. 


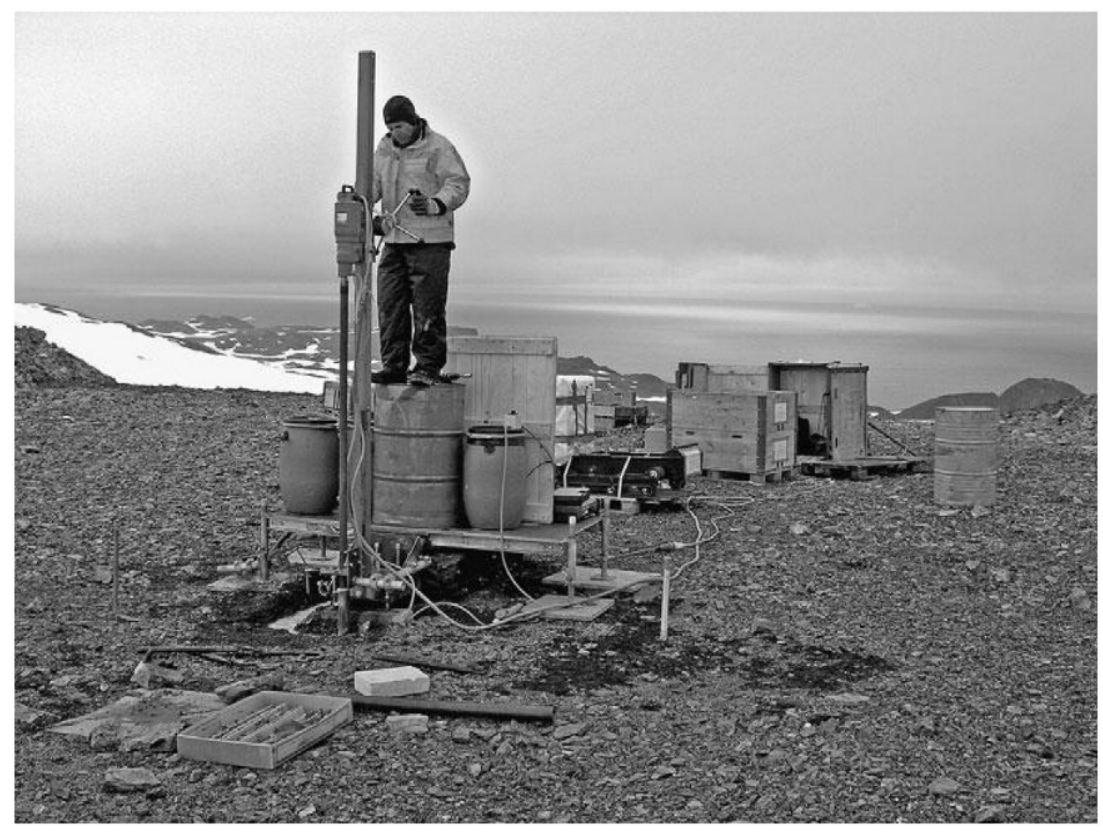

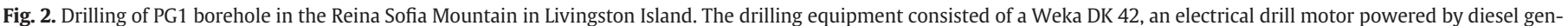
erators and a $3 \mathrm{~m}$ drill rig which was directly anchored on the rock.

temperatures are measured exactly in line to the scanning line. A third temperature is also measured "off line" to calculate thermal diffusivity. Thermal conductivity and thermal diffusivity measurements require the use of standards during the measurement procedure, which are rock samples with known thermal conductivities and thermal diffusivities (Popov, 1985).

Heat production by radioactive decay was also estimated for the PG1 borehole. A 8192-channel gamma-ray spectrometer Cicero (crystal $\mathrm{NaJ}(\mathrm{Tl})$ ) was used to determine the contents in uranium, thorium and potassium from the rock material from the borehole. Because about $1 \mathrm{~kg}$ of rock material is necessary to determine the contents in uranium, thorium and potassium of a rock sample, which must be ground, and because the cores should not be destroyed for other analysis and future preservation, and also because it is not expected to have high variations of heat production for such a short depth range, it was decided to use chips from two sections of the borehole to obtain the necessary mass of rock material for the analysis; the first section corresponds to a depth interval of 2 to $12 \mathrm{~m}$; the second section corresponds to a depth interval of 12 to $25 \mathrm{~m}$. The heat production (HP) values were calculated using to the formula (Schön, 1996):

$$
\mathrm{A}=\rho \cdot\left(0.097 \cdot C_{U}+0.027 \cdot C_{\mathrm{Th}}+0.036 \cdot C_{\mathrm{K}}\right)
$$

where $A$ is the heat production in $\mu \mathrm{W} / \mathrm{m}^{3}, \rho$ is the rock sample density in $\mathrm{g} / \mathrm{cm}^{3}, \mathrm{C}_{\mathrm{U}}, \mathrm{C}_{\mathrm{Th}}$, and $\mathrm{C}_{\mathrm{K}}$ are the relative contents in uranium, thorium, and potassium in units as indicated in Table 2. Table 2 also shows the values of the heat production for those two sections along the borehole. The density of $2.7 \mathrm{~g} / \mathrm{cm}^{3}$ was used to calculate the heat production by Eq. (1) in the two above-mentioned sections; that value is the average of the density values estimated for each of the cores in Table 3.

Porosity and density were also estimated for several cores from PG1 borehole using saturation and buoyancy techniques (Franklin et al., 2007). With those porosity values thermal conductivities for the cores filled with water and ice were calculated using the following expression (Beardsmore and Cull, 2001):

$\lambda_{\mathrm{s}}=\lambda_{\mathrm{m}}^{1-\phi} \cdot \lambda_{\mathrm{p}}^{\phi}$ where $\lambda_{s}$ is the average thermal conductivity of the rock sample, $\lambda_{\mathrm{m}}^{1-\phi}$ is the thermal conductivity of the rock matrix, and $\lambda_{\mathrm{p}}^{\phi}$ is the thermal conductivity of the material that fills the pores (water or ice).

\section{Results}

From a lithological point of view the cores from the borehole indicate that the section of the borehole to a depth of about $25 \mathrm{~m}$ depth is mainly composed of siltstones; from $25 \mathrm{~m}$ deep to the bottom of the borehole, the borehole crosses quartz sandstones. Thin sections were prepared and petrographic analysis shows that the silts are well calibrated and in the matrix have quartz grains and several other lithoclasts. The quartz sandstone is composed of feldspar (essentially plagioclase) and calcite crystals.

The values of thermal conductivity measured in the cores can be seen in Table 1 and vary between 2.6 and $3.3 \mathrm{~W} / \mathrm{mK}$. The values of thermal diffusivity are also presented in Table 1 and vary between $1.1 \times 10^{-6}$ and $1.6 \times 10^{-6} \mathrm{~m}^{2} / \mathrm{s}$.

Uranium, thorium and potassium contents as well as the heat production (HP) values (Table 2) for the upper and lower sections of the borehole are, respectively, $2.218 \mu \mathrm{W} / \mathrm{m}^{3}$ and $2.173 \mu \mathrm{W} / \mathrm{m}^{3}$ which are compatible with acidic rock types.

For completeness, density and porosities are also presented in Table 3 for the same cores as in Table 1, as well as the thermal conductivity values corrected for the pores filled with air (dry), water and ice.

Table 1

Thermal conductivity and thermal diffusivity measured in seven cores from borehole PG1.

\begin{tabular}{lll}
\hline $\begin{array}{l}\text { Depth of sample } \\
(\mathrm{m})\end{array}$ & $\begin{array}{l}\text { Thermal conductivity } \pm 0.1 \\
(\mathrm{~W} / \mathrm{mK})\end{array}$ & $\begin{array}{l}\text { Thermal diffusivity }\left(\times 10^{-6}\right) \pm 0.1 \\
\left(\mathrm{~m}^{2} / \mathrm{s}\right)\end{array}$ \\
\hline 4.3 & 2.7 & 1.1 \\
5.8 & 2.6 & 1.1 \\
9.6 & 2.6 & 1.1 \\
15.2 & 2.6 & 1.1 \\
20.4 & 2.7 & 1.2 \\
24.3 & 2.7 & 1.2 \\
25.9 & 3.3 & 1.6 \\
\hline
\end{tabular}


Table 2

Heat production estimates for the upper half and the lower half of the PG1 borehole. Eq. (1) in the text was used to calculate the heat production values.

\begin{tabular}{lllll}
\hline $\begin{array}{l}\text { Depth range } \\
(\mathrm{m})\end{array}$ & $\begin{array}{l}\text { Uranium } \\
\text { (p.p.m.) }\end{array}$ & $\begin{array}{l}\text { Thorium } \\
(\text { p.p.m. })\end{array}$ & $\begin{array}{l}\text { Potassium } \\
(\%)\end{array}$ & $\begin{array}{l}\text { Heat production }(\mathrm{A}) \\
\left(\mu \mathrm{W} / \mathrm{m}^{3}\right)\end{array}$ \\
\hline $2-12$ & 3.539 & 13.199 & 3.652 & 2.218 \\
$12-25$ & 3.707 & 12.614 & 3.607 & 2.173 \\
\hline
\end{tabular}

\section{Thermal diffusivity from temperatures in PG1 borehole}

PG1 borehole is cased and a chain of thermistors was installed in it on January 30, 2008; thermistor's depths are $0.2,0.4,0.8,1.2,1.6,2,2.5,3$, $3.5,4,5,6,8,10,12.5,15,17.5,20,22.5$ and $25 \mathrm{~m}$, and temperature is measured every 5 min; hourly averages (maximum and minimum temperatures) are stored in a datalogger.

The temperature time series read by each thermistor can be used to calculate the thermal diffusivities for different depths (Carslaw and Jaeger, 1959; Horton et al., 1983; Hurley and Wiltshire, 1993). If we assume that heat transfer is only by conduction in the vertical direction, and the ground is homogeneous and isotropic, thermal diffusivity $(\alpha)$ can be calculated from ground temperatures by integrating the heat conduction equation

$\frac{\partial \mathrm{T}}{\partial \mathrm{t}}=\alpha \frac{\partial^{2} \mathrm{~T}}{\partial \mathrm{z}^{2}}$

with the periodic boundary condition of period $2 \pi / \omega$

$\mathrm{T}(\mathrm{z}=0, \mathrm{t})=\mathrm{T}_{0}+\mathrm{A}_{0} \sin \left(\omega \mathrm{t}-\varepsilon_{0}\right)$

where $\mathrm{T}$ is the temperature, $\mathrm{t}$ is the time, $\mathrm{z}$ is the depth, $\mathrm{T}_{0}$ is the surface temperature, $A_{0}$ and $\varepsilon_{0}$ are, respectively, the amplitude and the phase of the surface wave temperature. The distribution of temperature as a function of time and depth is

$\mathrm{T}(\mathrm{z}, \mathrm{t})=\mathrm{T}_{0}+z \cdot \operatorname{gradT}+\mathrm{A}_{0} \cdot \mathrm{e}^{-\mathrm{z} / \mathrm{d}} \cdot \sin \left(\omega \mathrm{t}-\mathrm{z} / \mathrm{d}-\varepsilon_{0}\right)$

where grad T is the geothermal gradient and $d=\sqrt{2 \alpha / \omega}$. Eq. (5) can be used to calculate thermal diffusivity within a given layer by using or the amplitude or the phase lag of the temperature wave at depths $z_{1}$ and $z_{2}$. As a matter of fact, using the amplitude decrease between those two depths the thermal diffusivity is given by

$\alpha=\frac{\omega \cdot\left(\mathrm{z}_{1}-\mathrm{z}_{2}\right)^{2}}{2 \cdot \ln \left(\mathrm{A}_{1} / \mathrm{A}_{2}\right)^{2}}$

where $A_{1}$ and $A_{2}$ are the amplitudes of the temperature wave at depths $z_{1}$ and $z_{2}$, respectively, and $\alpha$ is the thermal diffusivity in the depth interval $z_{1}-z_{2}$. However, to apply Eq. (6) it is necessary to fit a sinusoid

\section{Table 3}

Density and porosity of the cores where thermal conductivity and thermal diffusivity were measured (Table 1). T.C. air, T.C. water, and T.C. ice refer to thermal conductivities of the cores with the pores filled with air (measured), with water (calculated using Eq. (2)), and with ice (calculated using Eq. (2)).

\begin{tabular}{llllll}
\hline $\begin{array}{l}\text { Core depth } \\
(\mathrm{m})\end{array}$ & $\begin{array}{l}\text { Density } \\
\left(\mathrm{kg} / \mathrm{m}^{3}\right)\end{array}$ & $\begin{array}{l}\text { Porosity } \\
(\%)\end{array}$ & $\begin{array}{l}\text { T.C. air }( \pm 0.1) \\
(\mathrm{W} / \mathrm{mK})\end{array}$ & $\begin{array}{l}\text { T.C. water } \\
(\mathrm{W} / \mathrm{mK})\end{array}$ & $\begin{array}{l}\text { T.C. ice } \\
(\mathrm{W} / \mathrm{mK})\end{array}$ \\
\hline 4.3 & 2700 & 2.3 & 2.7 & 2.9 & 2.9 \\
5.8 & 2704 & 2.1 & 2.6 & 2.7 & 2.8 \\
9.6 & 2715 & 1.5 & 2.6 & 2.7 & 2.7 \\
15.2 & 2700 & 1.9 & 2.6 & 2.8 & 2.9 \\
20.4 & 2715 & 1.8 & 2.7 & 2.9 & 2.9 \\
24.3 & 2704 & 2.7 & 2.7 & 2.9 & 3.0 \\
25.9 & 2643 & 2.0 & 3.3 & 3.5 & 3.6
\end{tabular}

function to the temperature data, which can be seen in Fig. 3 for the temperature time series for 3.5 and $6 \mathrm{~m}$ depth. As an example, using values from the sinusoid functions of Fig. 3 (which are the best-fit sinusoids to the actual temperature data calculated by the graphing package used to draw the graphs) and Eq. (6) the calculated thermal diffusivity is $2.2 \times 10^{-6} \mathrm{~m}^{2} / \mathrm{s}$, which is about the double of the values measured for depths between 3.5 and $6 \mathrm{~m}$.

\section{Discussion}

From all the properties presented in Tables 1,2 and 3, thermal conductivity and thermal diffusivity are the essential ones to describe and understand the thermal regime of the ground. This is particularly important in permafrost areas where climatic change is imposing fast changes in permafrost evolution and spatial distribution. In general terms the measured values for the thermal conductivity vary from 2.6 to $3.3 \mathrm{~W} / \mathrm{mK}$ (see Table 1 ) with the highest value for the measurement performed in the deepest core. This result is consistent with the fact that below the depth of $25 \mathrm{~m}$ the borehole traverses quartz sandstones. The same behavior is observed for the thermal diffusivity: the measured values vary from $1.1 \times 10^{-6}$ to $1.6 \times 10^{-6} \mathrm{~m}^{2} / \mathrm{s}$ (see Table 1 ), with the highest thermal diffusivity measured in the core obtained from the deepest portion of the borehole. Because the area where the PG1 was drilled goes through freezing and thawing processes during the year, estimates of thermal conductivity with the pores filled with air, water and ice were also done. Even though porosity is small for the rock of the cores, there is a significant change in their thermal conductivity, the highest values obtained for the pores filled with ice, as should be expected.

An interesting result emerges from the comparison between the thermal diffusivity values that were measured in the cores and the values that were obtained by using the theory of heat conduction briefly presented in Section 5. Only for the depth range of 3.5$6.0 \mathrm{~m}$, the difference between those values is about the double. Since the temperatures in that section of the borehole are lower than $0{ }^{\circ} \mathrm{C}$ (Fig. 4), the difference cannot be a result of thawing and freezing in that layer. The explanation must be looked for in the layers above $3.5 \mathrm{~m}$ and on the physical processes occurring in the active layer, i.e., in the energy balance that takes place at the surface of the

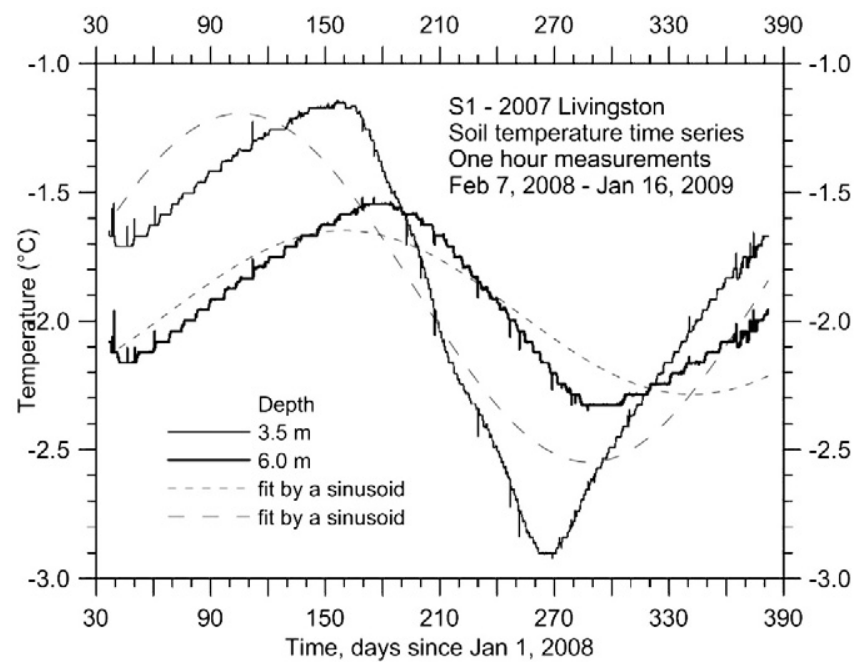

Fig. 3. Time series temperature at 3.5 and $6.0 \mathrm{~m}$ depths. Dashed lines are the best fit sinusoids to the temperature data. The coincidence is not very good and the probable explanation for this lack of coincidence must be a result of what happens at shallower depths, in the active layer of the area where the borehole is located. However, the conductive character of the downward propagation of the periodic signal is obvious from the amplitude attenuation and the phase delay. 
Temperature $\left({ }^{\circ} \mathrm{C}\right)$

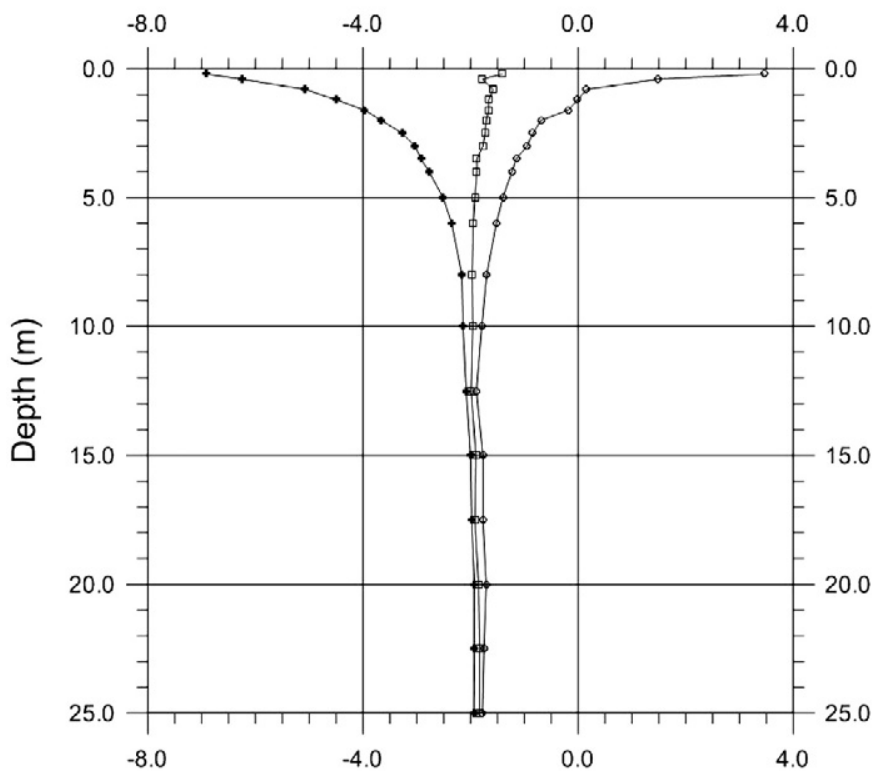

Fig. 4. Eleven-month ground temperature envelopes for the PG1 borehole for the period February 2008-January 2009. The depth of the ZAA is about $12.5 \mathrm{~m}$. Crosses, squares and diamonds represent minimum, mean and maximum temperatures, respectively.

ground. More research on the measurement of thermal properties at temperatures lower than $0{ }^{\circ} \mathrm{C}$ as well as a more detailed analysis of temperature changes at the surface of the ground will be attempted in the future.

At the time this paper is being written, there is no possibility of estimating the heat flow density. As a matter of fact the data obtained up to now are not clear in terms of calculation of the background or deep geothermal gradient, which is fundamental to calculate the heat flow density. The calculation of those two quantities will be attempted in the near future after downloading the latest temperature information in the Antarctica campaign of 2011 which is starting now.

Heat production is also important to understand the thermal regime in the ground and to extrapolate temperatures to depths not reached by boreholes. With that in mind heat production was estimated for two sections in the PG1 borehole, as described in the previous section. The calculated values $\left(2.218 \mu \mathrm{W} / \mathrm{m}^{3}\right.$ for the first half of the borehole and $2.173 \mu \mathrm{W} / \mathrm{m}^{3}$ for the second half) are consistent with values found in other regions of the globe for shales. However, they are too high for the quartz sandstone found in the last meter of the borehole; this results from the fact that only a small portion of the sandstone was present in the mixture of chips coming from a depth range of 12 to $25 \mathrm{~m}$.

Heat flow determinations and inversion of temperature logs from the borehole for climate change evaluation were not possible to do; new data from the summer campaign to start at the time of the writing of this paper will probably allow that calculation.

\section{Acknowledgments}

The authors thank the Fundação para a Ciência e Tecnologia (FCT) for funding the project PERMANTAR and Fundação Calouste Gulbenkian for funding the drilling of the Permamodel-Gulbenkian 1 (PG1) borehole. The M.Sc. student Paulo Amaral measured the density and the porosity of the cores. Thermal conductivities, thermal diffusivities, and heat productions of the cores were measured in the Geophysical Institute of Prague by Dr. Jan Safanda. The authors want to thank Vladimir Cermak, Enrique Serrano, and the guest editor for their useful and constructive comments and suggestions.

\section{References}

Amaral, P.M., Correia, A., Vieira, G., Ramos, M., Trindade, A., 2010. Thermal conductivity of corers collected in two boreholes drilled in Livinsgton Island (Maritime Antarctica). Preliminary results. In: Blanco, J.J., de Pablo, M.A., Ramos, M. (Eds.), Ambientes periglaciares, permafrost y variabilidad climática; II Congreso Ibérico de la International Permafrost Association. Universidad de Alcala, pp. 79-92 (in Portuguese).

Beardsmore, G.R., Cull, J.P., 2001. Crustal Heat Flow. A Guide to Measurement and Modelling. Cambridge University Press, Cambridge. 324 pp.

Blackwell, D.D., Steele, J.L., 1989. Thermal conductivity of sedimentary rocks: measurement and significance. In: Naeser, N.D., McCulloh, T.H. (Eds.), Thermal History of Sedimentary Basins. Springer-Verlag, New York, pp. 13-36.

Bockheim, J.G., 1995. Permafrost distribution in southern circumpolar region and its relation to the environment: a review and recommendations for further research. Permafrost and Periglacial Processes 6, 27-45.

Bockheim, J.G., Hall, K.J., 2004. Permafrost active layer dynamics and periglacial environments of continental Antarctica. South African Journal of Science 98, 82-90.

Carslaw, H.S., Jaeger, J.C., 1959. Conduction of Heat in Solids, 2nd edition. Clarendon Press, Oxford. 510 pp.

Franklin, J.A., Vogler, U.W., Szlavin, J., Edmond, J.M., Bieniawski, Z.T., 2007. Suggested methods for determining water content, porosity, density, absorption and related properties and swelling and slake-durability index properties. In: Ulusay, R., Hudson, J.A. (Eds.), The complete ISRM suggested methods for rock characterization, testing and monitoring: 1974-2006, pp. 83-93.

Guglielmin, M., 2006. Ground surface temperature (GST), active layer, and permafrost monitoring in continental Antarctica. Permafrost and Periglacial Processes 17, $133-143$.

Guglielmin, M., Cannone, N., 2011. A permafrost warming in a cooling Antarctica? Climate Change. doi:10.1007/s10584-011-0137-2

Guglielmin, M., Balks, M.R., Adlam, L.S., Baio, F., 2011. Permafrost thermal regime from two 30-m deep boreholes in Southern Victoria Land, Antarctica. Permafrost and Periglacial Processes 22, 129-139.

Hauck, C., Vieira, G., Gruber, S., Blanco, J., Ramos, M., 2007. Geophysical identification of permafrost in Livingston Island, Maritime Antarctica. Journal of Geophysical Research 112, F02S19, doi:10.1029/2006JF000544.

Horton, R., Wierenga, P.J., Nielsen, D.R., 1983. Evaluation of methods for determination apparent thermal diffusivity of soil near the surface. Soil Science Society of America Journal 47, 23-32.

Hurley, S., Wiltshire, R.J., 1993. Computing thermal diffusivity from soil temperature measurements. Computers and Geosciences 19, 475-477.

King, J.C., 1994. Recent climate variability in the vicinity of Antarctic Peninsula. International Journal of Climatology 14, 357-369.

King, J.C., Turner, J., 1997. Antarctic Meteorology and Climatology. Cambridge University Press, Cambridge, pp. 114-120.

Popov, Yu.A., 1985. Complex detailed investigations of the thermal properties of rocks on the basis of a moving point source. Izvestiya, Earth Physics 21, 64-70.

Ramos, M., Vieira, G., 2003. Active layer and permafrost monitoring in Livingston Island, Antarctic. First results from 2000 to 2001. In: Phillips, M., Springman, S.M., Arenson, L.U. (Eds.), Proceedings of the Eight International Conference on Permafrost, vol. 1. Balkema, Lisse, pp. 929-933.

Ramos, M., Vieira, G., Gruber, S., Blanco, J.J., Hauck, C., Hidalgo, M.A., Tome, D., Neves, M., Trindade, A., 2008a. Permafrost and active layer monitoring in the Maritime Antarctic: preliminary results from CALM sites on Livingston and Deception Islands. U.S. Geological Survey and the National Academies. USGS OF-2007-1047, Short Research Paper 070

Ramos, M., Vieira, G., Blanco, J.J., Gruber, S., Hauck, C., Hidalgo, M.A., Tome, D., 2008b. Thermal active layer monitoring in two different sites on Livingston Island during the last seven years: a comparative study. Proceedings of the Ninth International Conference on Permafrost, Fairbanks, Alaska. Institute of Northern Engineering, University of Alaska Fairbanks, Alaska, pp. 1463-1467.

Ramos, M., Hasler, A., Vieira, G., Hauck, C., Gruber, S., 2009. Drilling and installation of boreholes for permafrost thermal monitoring on Livingston Island in Maritime Antarctic. Permafrost and Periglacial Processes 20, 57-64.

Ramos, M., Vieira, G., Gruber, S., Pablo, M.A., Hidalgo, M.A., Correia, A., 2010. Thermal state of permafrost on the top of Reina Sofia mount, preliminary data. Livingston Island (Antarctica). In: Blanco, J. ., de Pablo, M.A., Ramos, M. (Eds.), Ambientes periglaciares, permafrost y variabilidad climática; II Congreso Ibérico de la International Permafrost Association. Universidad de Alcala, pp. 79-92 (in Spanish).

Schön, J.H., 1996. Physical properties of rocks: fundamentals and principles of petrophysics. Handbook of Geophysical Exploration. Section I, Seismic Exploration, v 18. Pergamon, Oxford. 583 pp.

Serrano, E., Lopez-Martinez, J., 2000. Rock glaciers in the South Shetland Islands, Western Antarctica. Geomorphology 35, 145-162.

Styszynska, A., 2004. The origin of coreless winters in the South Shetlands area (Antarctica). Polish Polar Research 25, 45-66.

Turner, J., Colwell, S.R., Marshall, G.J., Lachlan-Cope, T.A., Carleton, A.M., Jones, P.D., Phil, V.L., Reid, A., Iagovkina, S., 2005. Antarctic climate change during the last 50 years. International Journal of Climatology 25, 279-294.

Van de Berg, W.J., van den Broke, M.R., van Meijgaard, E., 2008. Spatial structures in the heat budget of the Antarctic atmospheric boundary layer. The Cryosphere 2,1-12. 